\title{
AZ EURÓPAI UNIÓ BŐVÍTÉSE ÉS A CSATLAKOZNI VÁGYÓK SZÁNDÉKAI A NÉPSZAVAZÁSOK TÜKRÉBEN
}

\author{
(The EU Enlargement and the Attitude of the Pre-Accession
} Countries in the Light of the Referendums)

\section{TEPERICS KÁROLY - RÓZSA PÉTER}

Kulcsszavak:

Európai Unió referendum Kelet-Közép-Európa

Az Európai Unió történetének legnagyobb léptékü bövitése zajlik napjainkban. Az eddigiektöl eltéróen sok ország, nagy területek, nagyszámú népesség kerül az Unió keretei közé. Közös jellemzöik határozottan eltérnek a "törzstagokétól", általában szegényebbek, jelenkori demokráciájuk sériülékenyebb. Érdekes közös jellemvonást ismerhetünk meg a csatlakozási népszavazásaik eredményeinek áttekintésekor is. Általában hosszú „elöszobázás" (10 év) után kerültek csak a szervezetbe, a végkifejlet referendumain kis részvétel mellett kerillt sor a belépési szándék szentesitésére. Mi húzódhat a népszavazások hasonlóságai mögött, a jövöben meddig lesz a blokk egységes, a régi tagoktól eltérō?

\section{Bevezetés}

Az európai integrálódás folyamatában a nemzetállami érdekek és a szupranacionális szerveződés ellentétének lehetünk tanúi. A kialakulás pillanatától jellemző, hogy a szervezetbe belépỏ tagok a nemzeti önállóságuk lehető legkisebb csorbítása mellett szeretnék a lehető legnagyobb hasznot realizálni. Ambivalens a szorosabb integrációhoz való hozzáállásuk, ennek eredményeként az intézményrendszer túlbürokratizált, a szervezet reformjai lassú folyamatok eredményeként valósulnak meg. Minden stratégiai döntés hátterében bonyolult alkufolyamatok húzódnak, a lényegi döntésekhez szükséges konszenzus csak nehezen születik meg. Napjaink nehéz döntései a bővítéshez és a vele párhuzamosan zajló reformfolyamatokhoz kapcsolódnak.

Tanulmányunkban a csatlakozás folyamatát, a csatlakozni vágyó országok szavazóinak szándékait vizsgáljuk, külön hangsúlyt adva a tagsági kérelem benyújtása és a csatlakozás között eltelt időtartamnak és a belépni szándékozók népszavazási döntéseinek.

\section{Az Unió bövitésének folyamata}

Az EGK létrejöttének pillanatától adott a bỏvülés lehetősége. A Római Szerzödés 237. pontja értelmében a Közösség bövítésének nincs jogi akadálya. Az Európai Uniós Szerződés O cikkelye ennek szinte szó szerinti átvételével (az EGK helyett értelemszerüen EU-ról beszél) úgy fogalmaz, hogy ,bármelyik európai állam 
Teperics Károly - Rózsa Péter : Az Európai Unió bővitése és a csatlakozni vágyók szándékai a népszavazások tükrében. Tér és Társadalom 18. évf. 2004/4. 135-148. p.

jelentkezhet az EU tagjának”. Problémát jelent az „európai” kifejezés értelmezése. Sem az EU Szerződés, sem más hivatalos dokumentum nem határozza meg pontosan, hogy mit takar az európai jelző. A szubjektív megközelítések mellett természetesen gyakorlatias feltételeket is megvizsgálnak a leendő tagok értékelésekor. Minden állam csatlakozhat, amelynek politikai és gazdasági felépítése megfelel az uniós elvárásoknak, és elfogadja a szervezet alapszerződésekbe foglalt értékrendjét, céljait.

A felvétel menete szabályozott. Az Európai Tanácshoz benyújtott jelentkezés után a Bizottság országvéleményt (avis) készít, aminek ismeretében dönt az Európai Tanács. Az Európai Parlament jóváhagyása után az egyes tagállamok és jelöltek parlamentjei ratifikálnak, és ezek után lehet a belépést véglegesnek tekinteni.

A bövítés a francia hegemóniával jellemezhető korai periódusban csak elvi lehetỏségnek tünt. 1973-ban először Nagy-Britannia, Dánia és Írország lépett be a szövetségbe. A tagok számának hatról kilencre emelkedése bizonyította, hogy a szervezet nyitott. De Gaulle elnöksége után vált mindez lehetövé, hiszen a francia elnök addig két alkalommal - 1963 januárjában és 1967 májusában - megvétózta a britek és „mezőgazdasági szállítóik” közeledését. Csak lemondása után, már Pompidou elnöksége idején kerülhetett sorra a bővítés.

A diktatórikus politikai berendezkedésből demokráciává alakuló dél-európai országok esetében politikai szándékok alapján döntöttek a felvétel mellett (Görögország 1981, Spanyolország, Portugália 1986). A demokratikus politikai berendezkedés stabilizálása fontosabb szempont volt, mint az adott országok gazdasági teljesítőképessége, így kerülhettek a szervezetbe fejlesztésre szoruló perifériák. A spanyol és portugál gazdaság egy före jutó bruttó hazai terméke az uniós átlag 70\%-át érte el csupán, gazdasági integrációjuk nem volt problémamentes (Nagy 1999).

$\mathrm{Az}$ 1995-ös bővülés a kétpólusú világrend megszünése utáni helyzetben a semlegesség értelmezhetetlenné válásával következett be. A gazdasági tekintetben uniós átlag felett tejesítỏ új tagok (Ausztria, Finnország és Svédország) szervezetbe integrálása könnyen megvalósult.

Új elem a bövülés folyamatában Kelet-Közép-Európa államainak közeledése. $\mathrm{Az}$ eddigi csatlakozásokhoz képest újdonság a belépni szándékozó országok nagy száma. Ezek az országok egytől-egyig az elmaradottabb gazdasággal rendelkezők közé tartoznak, egy före jutó bruttó hazai termékük az uniós átlag 40\%-a körüli értéket ér csak el. Szakadék található a belépni vágyók fejlettsége között is. Az új helyzet új reakciókat váltott ki a belsö reformfolyamatokkal bajlódó Unión belül is. Az Európai Megállapodás keretei között társult státuszt adtak a jelentkezőknek, anélkül, hogy a tagságot ígérték volna, és az eddigiektól eltérōen szigorú kritérium rendszert állítottak fel a leendő tagok számára.

1993 júniusában születtek meg a „koppenhágai kritériumok”, miszerint a leendö tagoknak stabil demokratikus intézményrendszerrel, emberi és kisebbségi jogokkal rendelkező jogállamoknak kell lenni, akik müködő piacgazdaságukkal bírják az Unión belüli versenyt, képesek a tagsággal járó kötelezettségek teljesítésére (beleértve a Monetáris Uniót, Schengeni Egyezményt stb.). Bár a leendỏ tagok számszerủ mutatókat szerettek volna, ezek csak általánosságban kerültek megfogalmazásra. A feltételek közé bekerült egy, az Unióra vonatkozó is. Az Uniónak is képesnek 
Teperics Károly - Rózsa Péter : Az Európai Unió bővitése és a csatlakozni vágyók szándékai a népszavazások tükrében. Tér és Társadalom 18. évf. 2004/4. 135-148. p.

kell lennie arra, hogy az integrációs folyamat veszélyeztetése nélkül be tudja fogadni az újakat. Az intézményi reformok és a bővítési folyamat összefüggését hivatott a kitétel érzékeltetni, eszerint szó sincs arról, hogy a Római Szerzödés betüje önmagában garantálná a bövítést (Csaba 1999).

1994 decemberében az Esseni Csúcstalálkozón megnevezték azokat az országokat, akik a jövőben tagok lehetnek. Az 1994 áprilisában beadott magyar, majd lengyel felvételi kérelem után úgy került a listára nyolc állam, hogy még nem is kérte a felvételét, sőt a baltiakkal és Szlovéniával még társulás szintjén sem volt kapcsolata az Uniónak. A ,puha kompromisszum” tipikus esete, amikor nem az integrációérettség, hanem az Unió maximális kiterjeszthetőségének határai kerültek megnevezésre (Balázs 1997). Minden állam belekerült, amit nem terhelt valami etnikai, politikai konfliktus a kontinens kelet-közép- és dél-európai területén.

1995-ben a Bizottság összeállította a „Fehér könyvet”, amelyben megnevezték azokat az intézkedéseket, közösségi elöírásokat, amelyek meghonosítása a jelölt országokban feltétel és cél is egyszerre. 1996-ban a leendö tagok kérdőíveket kaptak, amikben a Bizottság országjelentéseihez szolgáltattak adatokat. Ennek eredményeként 1997. július 17-én került nyilvánosságra az értékelés az "Agenda 2000" programcsomagban. 1997 decemberében a Luxembourgi Csúcson az „acquis” oszthatatlanságáról döntöttek, ennek értelmében a közösségi vívmányok csak egészben vehetők ât. Egyik oldalról a „másodrendủ tagság”, ,résztagság” rémképétől szabadulhattak meg a csatlakozni vágyók, másrészt ez a frissen érkezöknek kötelezettségeket is jelent, hiszen egyszerre az eddigieket meghaladó léptékủ nyitást kell végrehajtaniuk, mint bárkinek az eddigiek közül (Csaba 1999).

A „keleti bövítés folyamata” 1998. március 12-én a londoni Európa Konferenciával indult, ahol a tagok, tagjelöltek és Törökország képviselöi ültek egy asztal mellé. Ez utóbbi ország már nem került be a „csatlakozási folyamatba”, amit 1998. március 30-án indítottak a tagjelöltekkel, közülük a legjobb eredményt produkáló öt középeurópai országgal (Lengyelország, Csehország, Szlovénia, Magyarország és Észtország), valamint Ciprussal „kiscsoportos formában” kezdik meg a „tárgyalási folyamatot" 1998. március 31-én. Az 1999. december 10-11-én zajló Helsinki Csúcstalálkozó hozott stratégiai változást. A csatlakozási tárgyalásokba bevonták a „helsinki hatokat”, az időközben jelentkezését megújító Máltát, Lettországot, Litvániát, Szlovákiát, Bulgáriát, Romániát is. Alapvető változás ez a tárgyalások menetében, ez a „startvonalas” elképzelés megvalósulását jelenti.

2001-ben a Bizottság elemezte a csatlakozási tárgyalást folytató államok helyzetét, a tárgyalások elörehaladását, ennek alapján, a 2002. december 12-13-án Koppenhágában megtartott Európai Tanács ülésen az „Egyetlen Európa” címü nyilatkozatban bejelentették, hogy tíz ország befejezte a csatlakozási tárgyalásokat. Ök (Ciprus, Málta, Csehország, Észtország, Lengyelország, Lettország, Litvánia, Magyarország, Szlovákia, Szlovénia) 2003. április 16-án Athénban aláírták a csatlakozási dokumentumot, és 2004. május 1-jén ténylegesen is tagok lettek. Állampolgáraik a 2004 júniusában bekövetkező Európa Parlamenti választásokon már választhattak. Két ország (Románia és Bulgária) várhatóan 2007-ben fog csatlakozni, Törökország pedig nem kapott konkrét időpontot. 


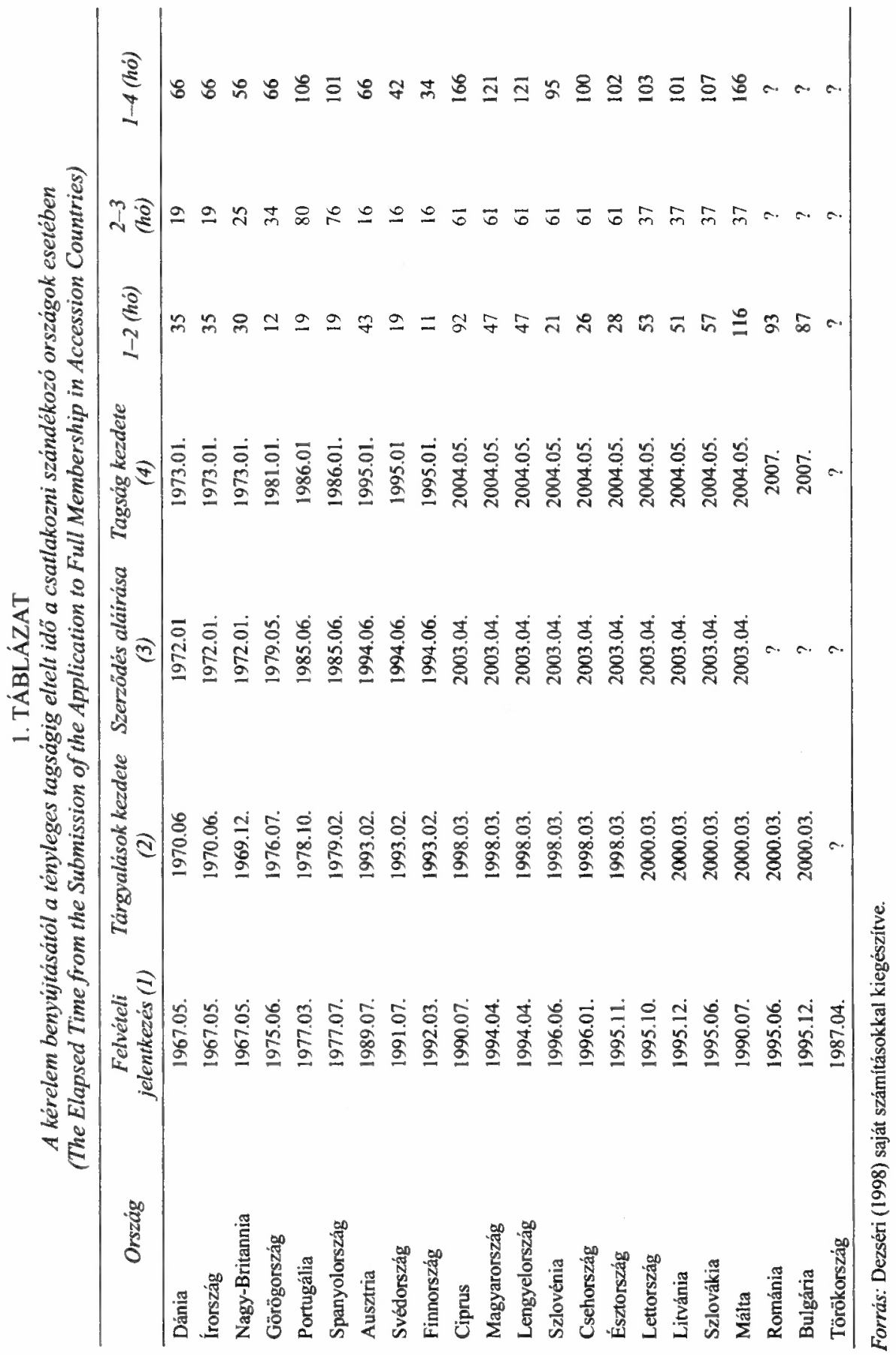


Teperics Károly - Rózsa Péter : Az Európai Unió bővitése és a csatlakozni vágyók szándékai a népszavazások tükrében. Tér és Társadalom 18. évf. 2004/4. 135-148. p.

TÉT XVIII. évf. 2004 『 4

Kitekintö

139

Az egyes csatlakozások eltérỏ pillanatban, eltérő fogadókészséggel találkoztak. Az eltérések jól követhetők a csatlakozási kérelmek benyújtásától a belépésig eltelt időtartamokkal (1. táblázat, 1. ábra).

Ezek alapján azonos vagy közel azonos várakozási periódusokkal rendelkező csoportokat különböztethetünk meg. A Földközi-tengeri szigetországok ,elöszobáztak” a leghosszabb ideig. Ciprus etnikai megosztottsága eredményezett fenntartásokat, végül az aláírt csatlakozási egyezmény sem terjed ki a török közösségre, amíg a sziget megosztott marad; Málta az 1990. június 16-án benyújtott csatlakozási kérelmét 1996-ban lemondta, és csak 1998 szeptemberében jelentette be újra csatlakozási szándékát, tehát ingadozása eredményezte a hosszú periódust (1.ábra).

\section{1. ÁBRA}

A csatlakozási kérelemtöl belépésig eltelt idö

(The Time from the Submission of the Application to Full Membership)

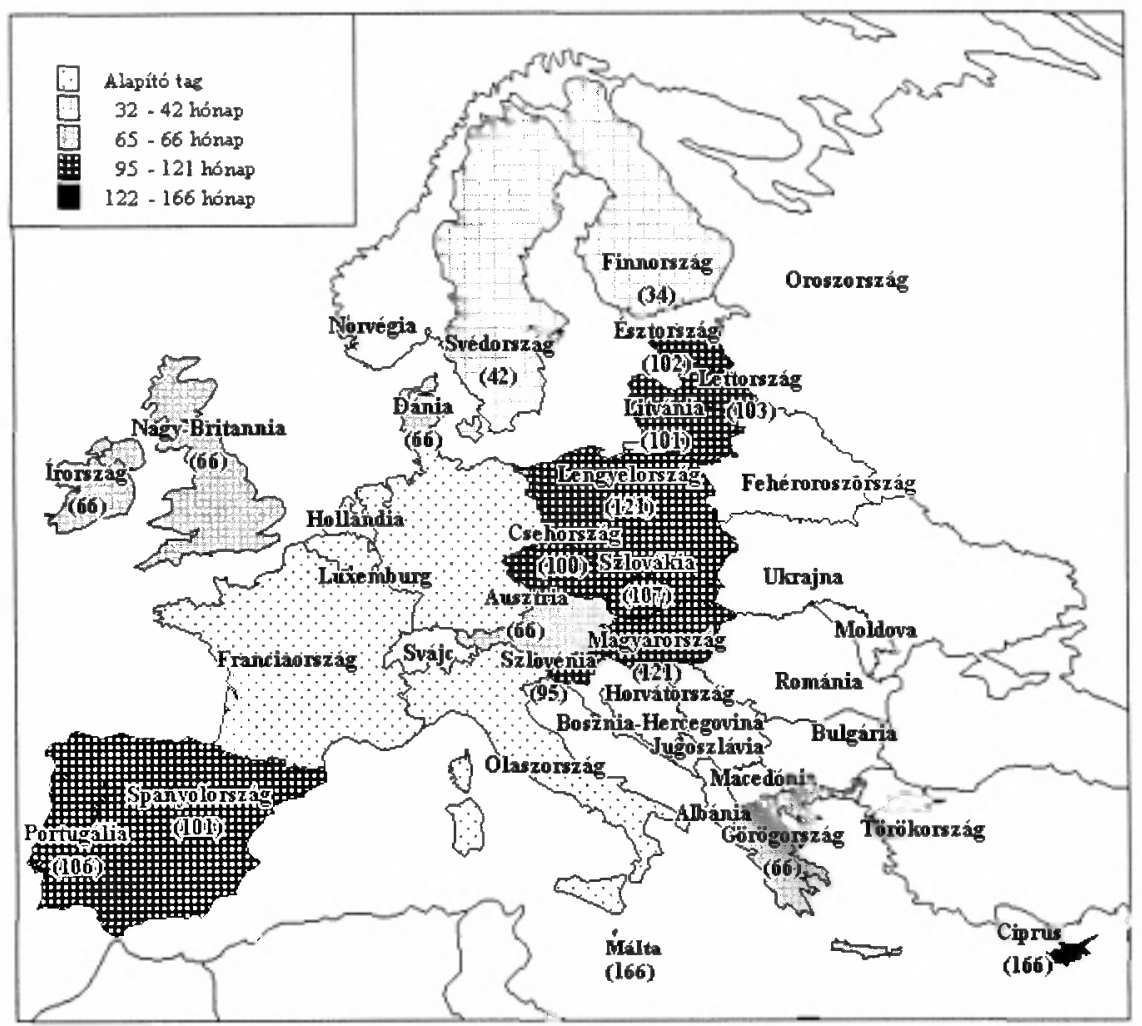

Forrás: Saját szerkesztés.

A modernizációval, gazdasági- és politikai rendszerváltással egyszerre küzdô Kelet-Közép-Európa országai alkotják a következő határozott csoportot. Az átlagnál valamivel hosszabb idő után, 100 hónap körüli felkészüléssel kerültek csak a szervezet közelébe, közben jórészt önerőböl kellett megvalósítaniuk az alkalmazkodás 
Teperics Károly - Rózsa Péter : Az Európai Unió bővítése és a csatlakozni vágyók szándékai a népszavazások tükrében. Tér és Társadalom 18. évf. 2004/4. 135-148. p.

feladatait. Időközben az Unió reformfolyamatainak szükségszerüsége is nyilvánvalóvá vált, a szervezet számára „saját belső gondjai által lévén elfoglalva, a bővítés semmiképp sem tünik sürgetőnek" (Csaba 1999). A csoporton belüli eltérések nem érdemi, inkább formai okoknak köszönhetök. Nincs szoros összefüggés a csatlakozási kérelem benyújtása és a gazdasági fejlettség között. A felkészuiltebb, korábban tagságért folyamodó országok (Lengyelország, Magyarország) hosszabb idő után kerülttek be, mint a csatlakozási folyamatba később bevont országok (Szlovénia).

Sorban utánuk a gazdaságuk tekintetében fejletlenebb Dél-Európa országai következnek. Láthatóan komoly dilemma előzte meg Spanyolország és Portugália felvételét. Ebben már a meglepóen rövid várakozás után körön belülre került, de gazdasági életében csak nehezen éledỏ Görögország kapcsán nyert tapasztalatok is szerepet játszhattak.

A másik végletet a skandináv államok Finnország, Svédország és Ausztria jelentik. Sokkal rövidebb idő alatt (átlagban negyede/ötöde a felkészülés náluk) alkalmazkodtak az elvárásokhoz (1. ábra).

\section{Akik kívül maradnak}

Az Unión kívüli országok jól alátámasztják a gazdasági jólét észak-dél vagy nyugat-kelet dichotómiáját. Az országok egyrésze önként maradt kívül az integráción, ezek főképp a gazdag észak/nyugat megjelenítói. Észak-Európa néhány országa/autonóm területe és Svájc sorolható ide. Általában a jóléti társadalmak közé tartoznak, vélhetően nem jelentene számukra elönyt a tagság. Szegényebb déli/keleti államok, bár szeretnének, de nehezen kerülnek közel a szervezethez.

Norvégia esete a „gazdagok” példázata. A „büszke periféria” (Gallai 1995) négy alkalommal keruilt a Közösség közelébe. Az első kettő a követendö példának tekintett britek csatlakozási szándékával párhuzamosan, De Gaulle francia elnök vétójával hiúsult meg. 1962-ben és 1967-ben elutasították felvételi kérelmüket, a következő két alkalommal pedig a politikai vezetők által benyújtott csatlakozási kérelem és a szervezet fogadó készsége ellenére az állampolgárok népszavazáson akadályozták meg a belépést. 1972. szeptember 26-án 79,2\%-os részvétel mellett 53,5\%-os nemmel, 1994. november 28-án magas, $89 \%$-os részvétellel 52,2\% ellenszavazattal önként maradtak kívül az Unión. A helyzet különlegessége, hogy a Britanniához füzödő hagyományosan jó kapcsolat ellenére döntöttek így. A „bármit tegyen is az Egyesuilt Királyság, Norvégiának is azt kell tennie" elvet nehezen rúgták fel. Már 1962-ben éles vita előzte meg a kérdést, de a francia "nem" feloldotta a belpolitikai konfliktust. 1967-ben számítható volt az ismétlódő elutasitás, nem is okozott feszültséget a kérdés, 1972-ben pedig a „nép gyözött az elit felett” (Gallai 1995), a fundamentalisták (farmerek, halászok képviselöi) leszavazták az „igen” mellett voksoló politikusokat, közigazgatási vezetöket és a nagy gazdasági szervezetek képviselöit. Az 1994-es szavazásig eltelt időszak lényeges változásokat is eredményezett a norvég gazdaságban. A felfutó kőolajtermelés nyújtotta extra jövedelmek, a stabilizálódó gazdaság, erős szociális háló nem tette feltétlenül szükségessé a 
Teperics Károly - Rózsa Péter : Az Európai Unió bővitése és a csatlakozni vágyók szándékai a népszavazások tükrében. Tér és Társadalom 18. évf. 2004/4. 135-148. p.

TÉT XVIII. évf. 2004 - 4

Kitekintö

belépést. A norvég gazdaság nemzetközi méretekben kicsi volta a felvásárlások, a hazainál enyhébb európai emissziós környezeti normák pedig a környezetrombolás veszélyét jelenthette volna a csatlakozás esetén. A nemzetközi együttmüködések kiterjesztésére törekvő kormány benyújtotta a csatlakozási kérelmet, de a népszavazás leállította a folyamatot.

Izland be sem adta a jelentkezését, hozzá hasonlóan Dánia néhány autonóm területe sem kér az integrációból. Az 1949-óta jelentős önállósággal bíró, 48000 lakossal rendelkezö Feröer szigetek a dán belépés pillanatától kimaradt, az önállóságát 1979-től megnövelő 55000 fös Grönland pedig 12 év tagság után, 1985-ben egyenesen kilépett az integrációból. Az 1982 márciusában 74,91\%-os részvétel mellett csak 45,9\%-os ,igen” aránnyal lefolytatott népszavazás ellenére az eltelt 18 év tapasztalatai erösítik az Unióhoz való újabb közeledést.

Svájc helyzete figyelemre méltó. A nemzetközi szervezetektöl tartózkodó ország 1992. május 20-án felvételét kérte, de decemberben népszavazáson elutasították állampolgárai a belépést. A kapcsolatok ennek ellenére szorosak, öt éves tárgyalás után hét szerződést írt alá az Unióval 1999. június 21 -én. A személyek szabad mozgását, a légi és földi közlekedést, a kutatási és műszaki együttmüködést, a piacszabályozást, a mezőgazdaságot és a szabványok és termékbizonylatok kölcsönös elfogadását érintő, a gazdaság szinte teljes egészét átfogó megállapodás ellenére a polgárok 2001 márciusában népszavazáson 55\%-os részvétel mellett (77\% nem) utasították el a csatlakozási tárgyalások megkezdésére vonatkozó kormány általi kezdeményezést.

\section{Akik önszántukon kíviul rekedtek kint}

Jugoszlávia utódállamai közül egyedül Szlovénia került rövid időn belül a szervezet közelébe. Albánia elzárkózása, kései nyitása, a jugoszláv utódállamok polgárháborús helyzetük, Törökország alapvetöen emberjogi viszonyai miatt nem került be a csatlakozó államok közé. Az integrációs folyamatból nincsenek véglegesen kizárva, de csatlakozásuk jelenleg nem időszerü. Az Unió ezzel is igýekszik bizonyítani a csatlakozás folyamat jellegét, azt, hogy a csatlakozás nem csak a legfejlettebb keletés közép-európai országok felvételét jelenti, hanem folytatódik mindaddig, amíg akad az előfeltételeknek megfelelni tudó és akaró állam a kontinens területén. Az uniós közjogban a tágan értelmezett „bővítési folyamat” részesei ezek az államok is, az Unió 1999 májusában teljes jogú tagságot helyezett kilátásba Macedóniának, Albániának, Bosznia-Hercegovinának, Horvátországnak és a demokratikus Jugoszláviának is. A délkelet-európai "Stabilizációs és Társulási Folyamat" (SAP) országonként eltérő, ,testre szabott" szerződéses kapcsolatokat jelent, amelyekkel fokozatosan bevonják az EU struktúrákba a részt vevö országokat. A lehetséges tagjelöltek közül Macedónia és Horvátország áll legközelebb ehhez a státuszhoz. Horvátország 2003 februárjában be is nyújtotta felvételi kérelmét. Ivan Racan kormányfö szavaival „szeretnék elérni az utolsó vonatot”, 2004-es tárgyalás kezdéssel a 2007-ben csatlakozók közé kerülve. 2003 júniusában az erről nyilatkozó soros görög elnök, Kosztasz Szimitisz 2008 vagy 2009 évét látta alkalmasnak a csatlakozásra. 
Teperics Károly - Rózsa Péter : Az Európai Unió bővitése és a csatlakozni vágyók szándékai a népszavazások tükrében. Tér és Társadalom 18. évf. 2004/4. 135-148. p.

Egyedi Törökország helyzete. 1964-ben szerezte meg a társult státuszt, de a tagság még napjainkban is távolinak tủnik. 1989 decemberében a felvételi kérelme is az Európai Tanács elé kerủlt. Az emberi jogok rendezetlen helyzete miatt az ország nem felel meg az uniós tagság politikai feltételeinek. A csatlakozás érdekében a legfontosabb feladatként a kínzások gyakorlatának felszámolását, a hadsereg politikai befolyásának csökkentését és a törökországi kurd kisebbség jogainak bővítését várják el tỏlük. Gazdasága is okozhat problémát, bár aligha többet, mint Románia (Szigetvári 2002). A negatív országjelentések után nem meglepö, hogy a csatlakozási folyamatba legutóbb bekerült „helsinki hatok” közé sem tudot felzárkózni. Sikerként könyvelhette el, hogy ezen az Európai Tanács ülésen (Helsinki, 1999. december 10-11.) megerősítették az Európa Parlament 1999. október 6-i határozatát, miszerint Törökországnak joga van kérni a csatlakozást, hivatalosan tagjelöltnek minősítik. 2002. október 24-25-én a brüsszeli csúcstalálkozón, amikor a csatlakozási folyamat ütemtervét fogadták el, a résztvevők Törökországnak nem ajánlottak időpontot, 2004 decemberére halasztották az erre vonatkozó döntést. "Idôszerủsített" csatalakozási partnerségi programot dolgoztak ki számukra, a pénzỉgyi támogatások összegét 2004 és 2006 közötti periódusban 1,05 milliárd euróra emelték, ugyanakkor felhívták a törökök figyelmét arra, hogy az iraki konfliktus kapcsán kül- és biztonságpolitikai lépéseikkor maximálisan tartsák szem elött az Unió és tagországainak érdekeit. Günter Verheugen bővítési biztos bocsátkozott becslésbe 2003 áprilisában a török külügyminiszterrel folytatott megbeszélésen. Eszerint, ha Ankara teljesíti a politikai feltételeket, és a ciprusi kérdésben is megegyezésre jutnak, akkor 2005-ben elkezdődhetnek a csatlakozási tárgyalások és 2011-2012-re Törökország is bekerülhet a tagok közé.

Nem egyszerú feladat az Unió számára sem a 60 milliós iszlám ország felvétele. Szembe kell nézni azonban azzal a veszéllyel, hogy a halogatást egyértelmủ elutasításként kezelö fundamentalisták helyzetét erősíti a ,keresztény klub” távolságtartása. Radikalizálódásuk nemcsak gazdasági, hanem katonapolitikai tekintetben is veszélyezteti a stratégiai szerepet betöltő országgal való kapcsolatot.

A Szovjetunió utódállamai kủlön kategóriát képeznek. Oroszország esete tisztázódni látszik, nem szándékoznak rövid távon belépni az Unióba. A Közös Európai Gazdasági Tér (CEES) jelentheti a megoldást, ahol a négy szabadság elvét valósítanák meg 15-20 év távlatában. Egyik fél sem vállalt teljesíthetetlen kötelezettséget vagy irreális időhatárokat. Az utódállamok egyébként a Partnerségi és Együttmüködési Szerződés (PCA) 10 éves időtartamára a gazdasági és politikai együittmúködés kereteit rögzítették, és megteremtették a politikai dialógus fórumait. Gazdasági tekintetben számukra a WTO tagság is nehezen teljesíthetö feltételeket teremt, az Uniós társulás távoli lehetőségnek sem tủnik. Bonyolultabb a helyzet Moldova és Ukrajna esetében. Európai államként a tagság elérését tủzték célul, ennek érdekében az acquis communautaire egyoldalú átvételét is vállalták. Az Unió „üdvözli az Európa melletti döntést", de tagságot vagy társult tagsági státust véletlenül sem helyez kilátásba. A „posztszovjet” helyett választott „európai modell” legnagyobb problémája, hogy a dialógus szinte csak gazdaságon kívüli területeken folyik. 
Teperics Károly - Rózsa Péter : Az Európai Unió bővitése és a csatlakozni vágyók szándékai a népszavazások tükrében. Tér és Társadalom 18. évf. 2004/4. 135-148. p.

TÉT XVIII. évf. 2004 - 4

Kitekintő

143

\section{A csatlakozási népszavazások}

A bővítések történetében általában jellemző, hogy népszavazás szentesítette a tárgyalások végeredményeként létrejött csatlakozási szerzödést, azaz a közösség tagjává válást. Kivételt csupán az 1981 és 1986 közötti második szakasz országai, Görögország, Portugália és Spanyolország képviselnek. A 2. ábrán a két legfontosabb adat, a részvételi arány és az ,igen” szavazatoknak az összes érvényes vokson belüli aránya összefüggéseit próbáljuk bemutatni. (Az egyes referendumok végeredményeit lásd például a www.valasztas.hu honlapon.)

2. ÁBRA

A csatlakozásról népszavazó országok eredményei a részuétel és az igen szavazatok tükrében

(The Results of the Referendums in Countries by Participation and Supporting

Votes)

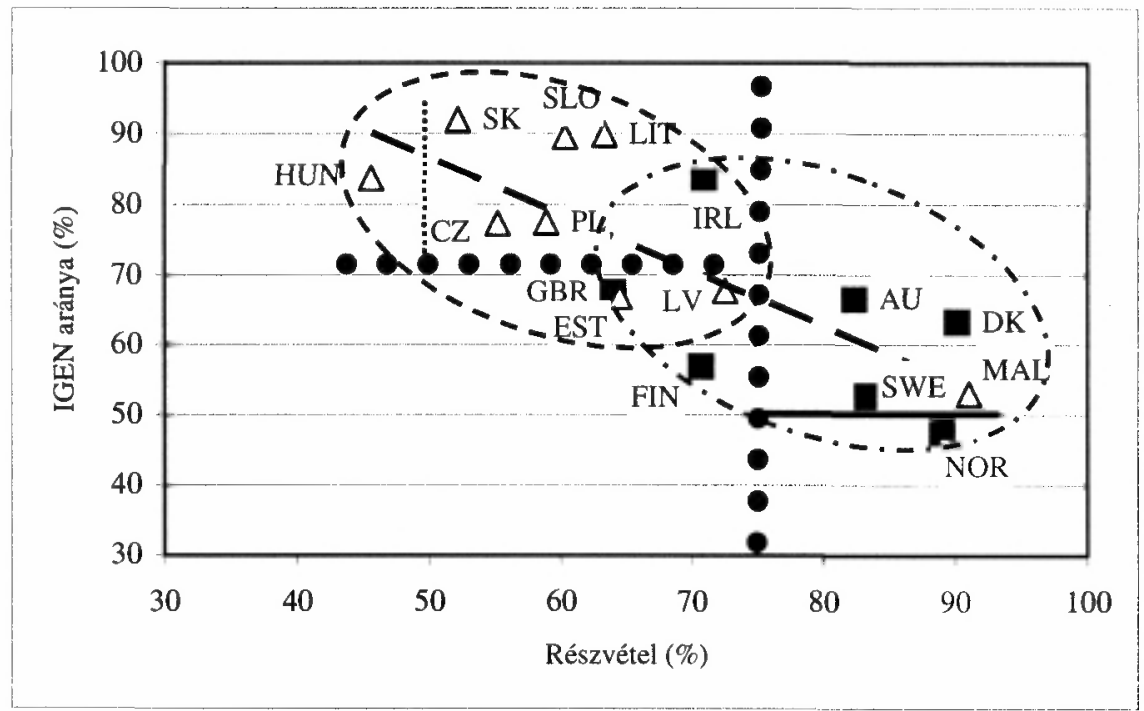

Forrás: Saját szerkesztés.

Az ábrán jól látszik a 2003. évi népszavazásokat megelőző referendumoknak az a közismert tapasztalata, hogy a részvételi arány és az, ,igen” aránya között határozott összefüggés állapítható meg, amennyiben a nagyobb szavazási hajlandóság az ,,igen” szavazatok arányának csökkenésével jár együtt. Az is megfigyelhető, hogy a meghúzható trendvonalat az adott országok pontjai két párhuzamos vonulatban követik: Írország, Ausztria és Dánia határozottan a trendvonal fölött, míg NagyBritannia, Finnország, Svédország és Norvégia markánsan az alatt helyezkedik el. A 2003. évi referendumok eredményei az általános trendet követik, sőt a trendvonallal párhuzamos kétosztatúság is megmarad. Figyelemre méltó ugyanakkor, hogy a kelet-közép-európai egykori „,szocialista” országok külön halmazba tömörülnek, 
mely a korábbi népszavazások pontjai alkotta halmazzal csupán csekély átfedésben van. E nyolc országtól markánsan elkülönül Málta.

Úgy véljük, hogy a részvételi arányban és a csatlakozást támogató ,igen” szavazatok arányában megmutatkozó különbségek, illetve az egyes államok referendumait jellemző portok sürüsödése alapján lehetőség nyílik ezen országok csoportosítására. A kategorizálással az általános jellemzöket igyekeztünk megragadni, ezért a részvételi arány és az ,igen" szavazatok aránya alapján is csupán két-két (aktív és passzív, illetve lelkes és szkeptikus), összesen tehát négy (aktiv, de szkeptikus; aktiv és lelkes; passzív és szkeptikus; passziv, de lelkes) csoportot állítottunk föl. A határok megvonásánál nem a parlamenti választások esetében elterjedt határokat követtük. Az 50\%-os részvételi és „igen” arány természetesen alapvető fontosságú az érvényesség, illetve a csatlakozás szempontjából, de ezen értékek valamelyikét csupán a magyarországi és a norvégiai referendumok nem érték el. A minősített többség (66\%), mint határvonal figyelembe vétele logikusnak tetszhet, de az ábrán jól látható, hogy - különösen az ,igen” szavazatok arányánál - sok ország értékei igen közel kerülnének e vonalhoz, s egyik vagy másik kategóriába való kerülésük akár 1-2\%-on múlna. Ezzel szemben mind a részvételi arány, mind az ,igen” szavazatok esetében megfigyelhető egy 10\%-nyi üres sáv, előbbinél nagyjából 72 és 82 , utóbbinál 65 és $75 \%$ között. Ezért az egyes kategóriákat e sávok mentén választottuk el egymástól. A 2. ábra diagramján alkalmazott hármas pontsorral is azt kívántuk kifejezni, hogy az egyes csoportok között nem határvonal, hanem elválasztó zóna jelölhető ki. Mindemellett föltüntettük az 50\%-os határvonalat is. A részvételi arány 50\%-os értékénél meghúzott vastag egyenes éles elválasztást jelöl, hisz a vonal alatti Norvégiában a szavazók nemet mondtak a csatlakozásra. A részvételi arány esetében vékony pontsort alkalmaztunk, mivel az csupán lélektani határt jelöl, hisz Magyarország esetében a referendum érvényességének nem feltétele, hogy a választók legalább fele szavazzon.

A fentiek alapján a következő csoportokat alakíthattuk ki:

1. Aktív, de az integráció ügyében szkeptikus országnak (80\% fölötti részvétel, de 55\% alatti ,igen" arány) bizonyult Málta és Svédország, valamint (extrém EU-szkeptikusként) a csatlakozást kétszer is elvetö Norvégia.

2. Aktiv és az integráció ügyében lelkes országnak (80\% fölötti részvétel és $60 \%$ fölötti ,igen” aråny) tekinthetö Ausztria és Dánia.

3. Passzív és az integráció ügyében szkeptikus országok (75\% alatti részvétel és 70\% alatti ,igen” arány) közé sorolható Nagy-Britannia, Észtország, Lettország és Finnország.

4. Passzív, az integráció ügyében lelkes országok ( $75 \%$ alatti részvétel, de $75 \%$ fölötti ,igen” arány) csoportjába tartozik Írország, Csehország, Lengyelország, Szlovákia, Szlovénia, Litvánia és (extrém passzívként) Magyarország. 
Teperics Károly - Rózsa Péter : Az Európai Unió bővitése és a csatlakozni vágyók szándékai a népszavazások tükrében. Tér és Társadalom 18. évf. 2004/4. 135-148. p.

TÉT XVIII. évf. 2004 - 4

Kitekintö

\section{A kelet-közép-európai országok csoportja}

A népszavazások jellemző adatainak a 3. ábrán belüli elhelyezkedésénél szembetủnő az, hogy a nyolc egykori kelet-közép-európai volt „szocialista ország” mindegyike „passzív”-nak, ráadásul hat ,passzív, de lelkes” országnak bizonyult. A konkrét értékeket természetesen az adott ország konkrét belpolitikai helyzete is lényegesen befolyásolta, ám úgy véljük, hogy a hasonló választói magatartást több, a napi politikán túlmutató közös tényezővel magyarázhatjuk.

\section{3. ÁBRA}

A népszavazások arányai és a segitségükkel megalkotható csoportok

(The Shares of Referendums and the Groups That Can be Created with Them)

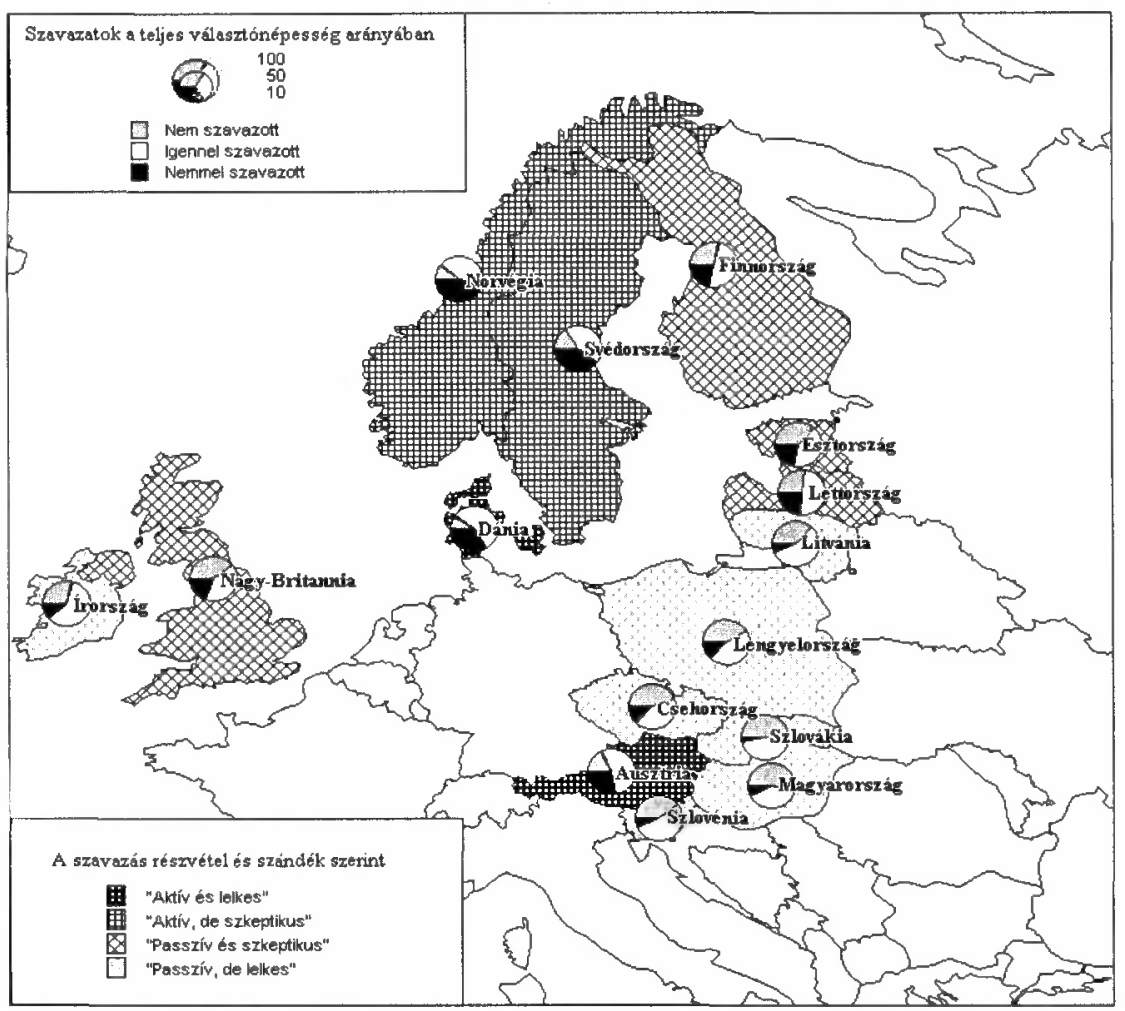

Forrás: Saját szerkesztés.

1. Nem hagyható figyelmen kívül e kelet-közép-európai államok történelmi „nyomorúsága" (Bibó 1946), vagyis az önálló állami lét (ha volt egyáltalán) több évszázadig tartó elvesztése. Különösen fontos lehet a sok tekintetben közös vonásokat mutató 20. századi történelem: az I. világháború után az önállóság teljes (vagy egy államszövetségen belüli részleges) meg-, illetve visszaszerzése; a második világháborút követóen a ,szocializmus építése” az önállóság teljes vagy jelentős 
Teperics Károly - Rózsa Péter : Az Európai Unió bővitése és a csatlakozni vágyók szándékai a népszavazások tükrében. Tér és Társadalom 18. évf. 2004/4. 135-148. p.

elvesztésével; a nyolcvanas évek végén, a kilencvenes évek elején az önállóság visszaszerzése, egyes esetekben megteremtése. Mindezek miatt az állami szuverenitás részleges föladásával szemben ezen országok választóinak komoly fönntartásai lehetnek. Ugyanakkor ezen országok közvéleményében erős az a hit, hogy az Európai Unióhoz való csatlakozás nem más, mint ,jóvátétel” a kỏzel(vagy távolabbi) múltban elszenvedett sérelmekért (pl. a jaltai „cserbenhagyás”), azaz valami, ami ,jár". Mindkét attitủd a választói passzivitást növeli, a támogatók és az ellenzők körében egyaránt.

2. Ezzel együtt az Európai Unióhoz való csatlakozás szükségességének elfogadásában a volt keleti blokk országaiban széleskörü konszenzus volt tapasztalható. Ez jelentette egyrészt azt, hogy ebben a kérdésben (Észtország és Lettország kivételével) a mértékadó politikai pártok (legyenek ellenzékben vagy kormányon) egyetértettek, másrészt azt, hogy - a kơzvélemény-kutatások szerint - az illető országok polgárainak meghatározó többsége is pártolta a csatlakozás gondolatát. Ez azzal járhatott, hogy a választók jó része a csatlakozást lényegében eldöntött tényként kezelte. Ennek fontosságára utal a 4. ábra, ahol a referendumok részvételi arányát a támogatók/ellenzők arányának függvényében ábrázoltuk.

\section{4. ÁBRA}

A volt szocialista országok referendumainak részvételi aránya a csatlakozást támogatók/ellenzók függvényében

(The Participation Shares in the Post Socialist Countries by Supporters/Opposers)

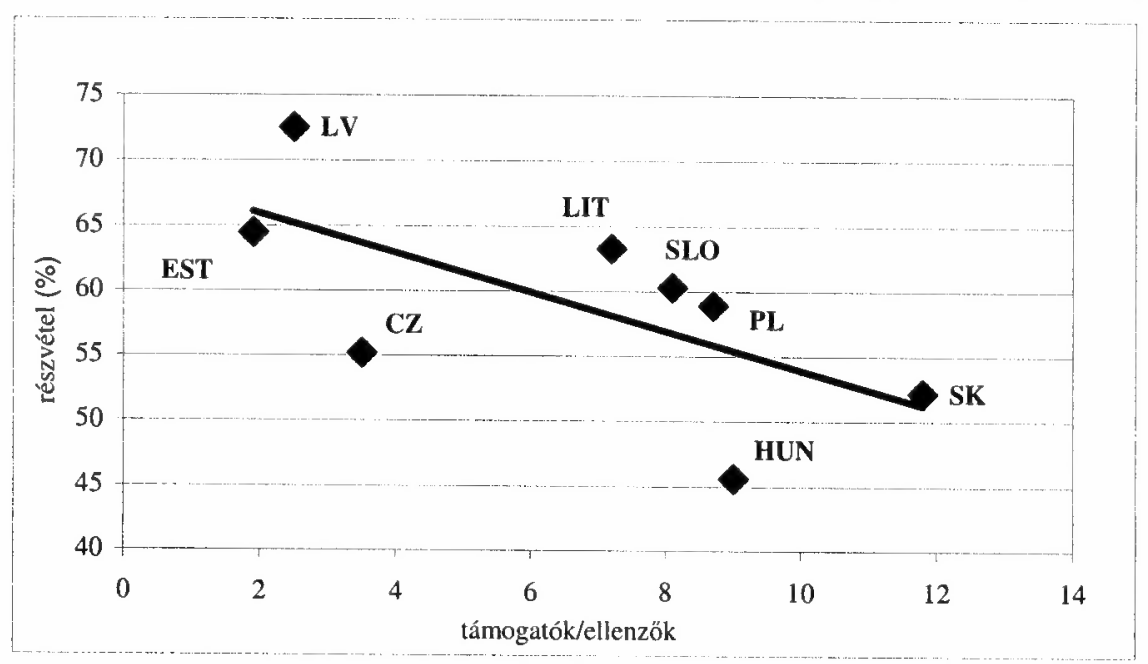

Forrás: Saját szerkesztés.

A támogatók/ellenzók arányt a népszavazási periódust közvetlenül megelőző 2003 elsö félévében végzett közvélemény-kutatási adatok alapján (Becsky 2003; Gallup Organisation Hungary 2003) számoltuk ki. Jól látható, hogy a támogatottság növekedése és a részvételi arány csökkenése között határozott összefüggés mutatkozik. Föltételezhetỏ, hogy a csatlakozást támogatók egy része nem tartotta 
Teperics Károly - Rózsa Péter : Az Európai Unió bővitése és a csatlakozni vágyók szándékai a népszavazások tükrében. Tér és Társadalom 18. évf. 2004/4. 135-148. p.

szükségesnek, hogy a biztosra vehetỏ ,igen”-t a népszavazáson való megjelenésével is megerősítse, az ellenzők egy része pedig eleve feleslegesnek ítellhette az egész referendumot.

3. A passzivitás oka lehet az is, hogy a csatlakozási folyamat rendkívül hosszú ideig tartott, 95 (Szlovénia) és 121 (Magyarország és Lengyelország) hónap közötti vârakozást jelentett. Ennek, valamint a csatlakozás lehetséges időpontjának megadása körüli bizonytalanságok (újabb és újabb, s természetesen egyre későbbi dátumok) következtében a közvéleményben egyfajta fásultság, érdektelenség alakulhatott ki. E következtetést támasztja alá az 5. ábra, melyen a csatlakozási referendumon mutatott választói aktivitásokat a csatlakozási folyamatok időtartamának függvényében ábrázoltuk. E diagramon az egykori keleti blokkba tartozó országok teljes mértékben és egyértelmúen elkülönülnek a korábban csatlakozók csoportjától.

\section{5. ÁBRA}

A népszavazási aktivitás a csatlakozási folyamat időtartamának függvényében (The Participation Interest by the Duration of the Accession Process)

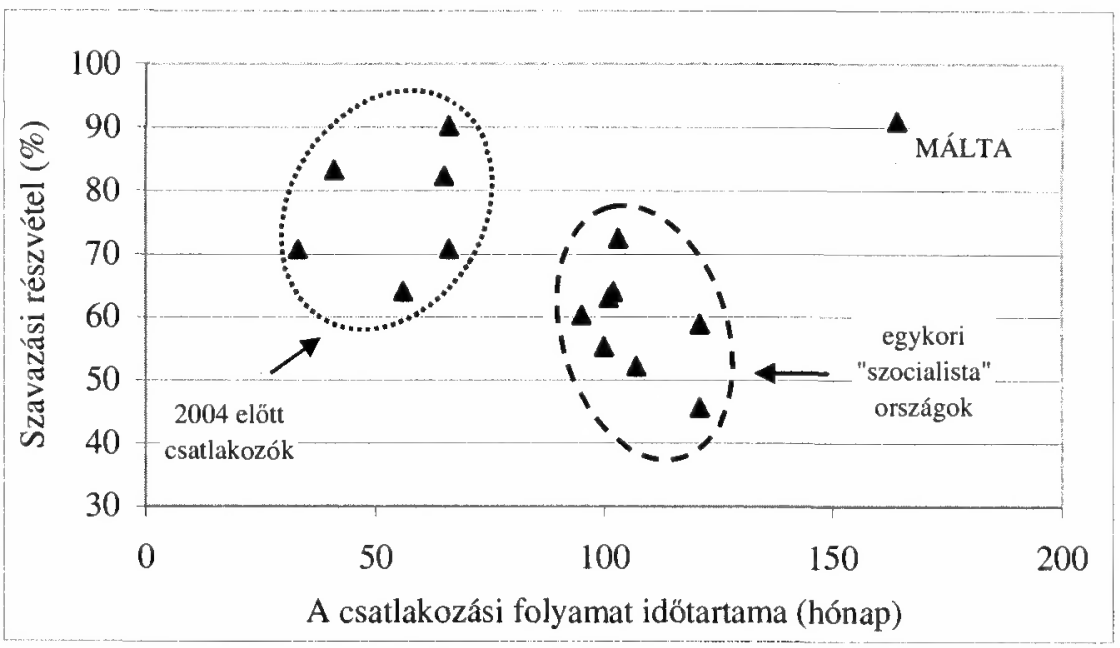

Forrás: Saját szerkesztés.

4. Az elmondottakból következik, hogy az a lelkesedés, amit az ,igen” szavazatok magas aránya jelez, csupán látszólagos, s nem elhanyagolható mértékben a nagyfokú választói passzivitás eredménye. Ugyanakkor az is jellemzö, hogy ezen országok közvéleményében még mindig erősek a csatlakozás utáni gyors fölzárkózásra és gazdasági föllendülésre vonatkozó (nem egyszer illuzórikus) elképzelések. Aligha véletlen, hogy a korábban csatlakozó országok közül az akkor ugyancsak a perifériához tartozó Írország népszavazási adatai esnek a hat volt szocialista országgal közös csoportba.

Külön kell szólnunk Észtországról és Lettországról. E két balti állam a többi kelet-közép-európai országtól határozottan elkülönülő helyzetét, a ,passzív és 
Teperics Károly - Rózsa Péter : Az Európai Unió bővitése és a csatlakozni vágyók szándékai a népszavazások tükrében. Tér és Társadalom 18. évf. 2004/4. 135-148. p.

szkeptikus" kategóriába kerülését alapvetỏen sajátos etnikai viszonyaik, a nemzeti (döntöen orosz) kisebbség jelentős, egyes becslések szerint a népesség harmadát is kitevő arányával magyarázhatjuk. Igaz ugyan, hogy az Európai Unióhoz történő csatlakozás az Oroszországtól való nagyobb mértékủ eltávolodást jelentheti számukra, ám azzal is jár, hogy a nemzeti kisebbségekkel szembeni eddigi diszkrimináció (pl. az állampolgárság megadásának, és ezáltal a választójognak a korlátozása) a továbbiakban aligha lesz fönntartható. A „nem” szavazatok meglepöen magas (kb. 30\%-os) arányához az is hozzájárulhatott, hogy e két országban parlamenti pártok is programjuk részévé tették az unió-ellenes kiállást, így a csatlakozást ellenzỏ álláspont a mindennapi politikai közbeszéd része lehetett.

Befejezésül hangsúlyozni szeretnénk, hogy a fentiekben ismertetett kategorizálás az adott országok választóinak csupán egy adott, ráadásul nem is azonos időpontban kifejezett viszonyulása alapján történt, azaz a „lelkes” és „szkeptikus” jelzök (csakúgy, mint a „passzív” és „aktív” kifejezések) alapvetően az e népszavazásokon megnyilvánuló hozzáállásra vonatkoznak. Arra is föl kell hívnunk a figyelmet, hogy a választói viszonyulás nem, vagy nem föltétlenül esik egybe az adott ország általános uniós politikájával, pl. a „szkeptikus” Finnország bevezette az eurót, míg a „lelkes” Dánia továbbra is megtartotta saját pénzét.

Meggyőződésünk ugyanakkor, hogy a referendumokon megnyilvánuló aktivitás hosszútávon ható tényezőkre is visszavezethető. Az elkövetkező évek európai uniós referendumainak eredményei alapján érdemes lesz megvizsgálni, hogy a volt keleti blokk országai megörzik-e különállásukat vagy változnak-e, s ha igen, hogyan és miért.

\section{Irodalom}

Balázs P. (1997) Integrációs csapdák az Európai Unió és Kelet-Közép-Európa kapcsolatában. - Közgazdasági Szemle. 11. 970-986. o.

Becsky R. (2003) Uniós közvélemény. - Külgazdaság. 7. 66-72. o.

Bibó I. (1946) A kelet-európai kisállamok nyomorúsága. - Vida I.-Nagy E. (szerk.) Bibó István válogatott tanulmányok Il. kötet. Magvetö Kiadó, Budapest. 185-265. o.

Csaba L. (1999) Stratégiai kérdések az Európai Unió keleti kibövủlésével kapcsolatban, - Külgazdaság. 7-8. 4-36. o.

Gallai S. (1995) Felszított európarázs. - Társadalmi Szemle. 3. 43-52. o.

Gallup Organisation Hungary (2003) EUROBAROMETER EB59-CC-EB. 2. Comparative Highlights.

Nagy A. (1999) A dél-európai országok európai integrációja és annak tanulságai I. - Közgazdasági Szemle. 2. 176-193. o.

Szigetvári T. (2002) Törökország - milyen hosszú a mézesmadzag? VKI, Budapest. 